\title{
“ SAND ENGINE " : BACKGROUND AND DESIGN OF A MEGA-NOURISHMENT PILOT IN THE NETHERLANDS
}

\author{
Jan P.M. Mulder ${ }^{1,2,3}$ and Pieter Koen Tonnon ${ }^{1}$
}

\begin{abstract}
Coastal policy in the Netherlands is characterised by three scale levels. The smallest scale is aimed at the preservation of safety agaisnt flooding by maintaining a minimum dune strength; the middle- and large scales at preservation of sustainable safety and of functions in the coastal zone by maintaining the coast line, respectively the sand volume in the coastal foundation. The definition of three scales basically implies a pro-active approach, based on the idea that the larger scale sets boundary conditions for the smaller scale. This pro-active approach appears to be succesful: nourishments since 1990 not only have resulted in maintaining the coast line, but also in an extension of the dunes, contributing to an increased safety against flooding. The succes has been achieved by a yearly nourishment volume of $12 \mathrm{Mm}^{3}$.

Recent studies have indicated the need to upscale the yearly averaged nourishment volume. A recent update of the sediment balance of the coastal foundation shows a negative total of ca. $20 \mathrm{Mm}^{3}$ per year; so apparently $12 \mathrm{Mm}^{3}$ nourishments per year is insufficient to maintain the total active sand volume of the system. Besides, in a study on future adaptation options to climate change in the Netherlands, the authoritive Deltacommissie (2008) even recommends a raise of nourishment budgets up to $85 \mathrm{Mm}^{3} /$ year until the year 2050, taking into account an ultimate worst case scenario of a sea level rise of $13 \mathrm{~cm}$ in 2100 .

To investigate innovative ways of nourishing larger volumes of sand, a Pilot project Sand Engine has been developed. The pilot implies a mega-nourishment of approximately $20 \mathrm{Mm}^{3}\left(\sim 10000 \mathrm{~m}^{3} / \mathrm{m}\right)$ on the coast of Holland, between Hook of Holland and The Hague. In the design phase of the pilot, a morphodynamic Delft $3 \mathrm{~d}$ model has been used to calculate morphological effects of several alternatives. The Environmental Impact Assessment EIA has decided on a shore attached cross shore bar with a length of ca. $1.5 \mathrm{~km}$, as the preferent alternative. Implementation is planned for 2011, starting december 2010 .
\end{abstract}

Keywords: mega-nourishment, coastal policy, morphodynamic modelling

\section{INTRODUCTION}

\section{North Sea coast of the Netherlands}

The Dutch coastline along the SE part of the North Sea (Fig. 1) is about $350 \mathrm{~km}$ long. Some $15 \%$ of the coast consists of sea dykes and other man made sea barriers, some $10 \%$ are beach flats along the tips of the northern Wadden islands, 75\% are dune areas of varying widths from less than 100 metres to several kilometres. The primary function of the coast is protection of the low-lying hinterland against flooding. The sandy coast however represents important values to other functions as well: ecological values, drinking water supply, recreation, residential and industrial functions. Coastal erosion, dominant along half of the Dutch coast, is endangering these functions.

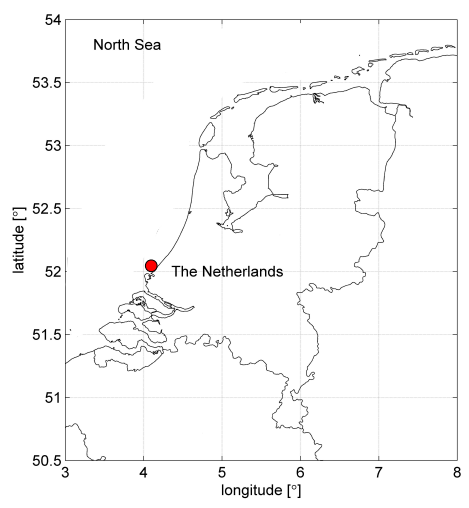

Figure 1 The Netherlands. Red dot indicates location of mega-nourishment Pilot Sand Engine.

\footnotetext{
${ }^{1}$ Marine and Coastal Systems, Deltares, P.O. Box 177, $2600 \mathrm{MH}$ Delft, The Netherlands

${ }^{2}$ Water Engineering and Management, University of Twente, P.O. Box 217, 7500AE Enschede, The Netherlands

${ }^{3}$ Netherlands Centre for Coastal Research / NCK, P.O. Box 177, 2600 MH Delft, The Netherlands
} 


\section{Nourishment policy in the Netherlands since 1990}

In order to stop structural erosion, in 1990 the Dutch government decided on a policy of "Dynamic Preservation", using nourishments as the prefered intervention to maintain the coast line. Defining the 1990 coast line position as the reference coast line (referred to as Basal Coast Line $\mathrm{BCL}$ ), the main objective of the policy is sustainable preservation of safety against flooding and of functions in the dune area.

In 2000 it was decided that in order to achieve sustainable preservation, it was necessary to extend the policy to a larger scale. In addition to the tactical objective of maintaining the coast line, a second (larger scale) tactical objective was defined: maintaining of the sand volume in the coastal foundation i.e. the active sand volume in the area between the $-20 \mathrm{~m}$ depth contour and the landward boundary of the dune massive. The annual average nourishment volume, $6 \mathrm{Mm}^{3}$ since 1990, was raised to $12 \mathrm{M} \mathrm{m}^{3}$ (see e.g. Van Koningsveld and Mulder, 2004).

In parallel to the policy of Dynamic Preservation of coast line and of coastal foundation, aimed at sustainable preservation of safety and of functions, the Water Safety policy aims at the preservation of momentanous safety against flooding. In a 5-yearly test procedure, the residual strength of all dunes is established under design conditions related to the local safety standard.

Considering the three different indicators - i.e. residual dune strength, basal coast line and coastal foundation -, Mulder et al. (2006) concluded that basically, coastal policy in the Netherlands i.e. both nourishment policy of Dynamic Preservation and the Water Safety policy - implies three different scale levels of management (Fig. 2). The distinction is based on the idea that the large scale sets boundary conditions for the smaller scales. E.g. preservation of residual dune strength creates boundary conditions for safety against flooding at any place and any moment, preservation of the Basal Coast Line (BCL) creates boundary conditions for preservation of the dune strength over a period of (10) years and alongshore distances of kilometers, whereas preservation of the Coastal Foundation in turn creates boundary conditions for preservation of the BCL over decades to centuries and over alongshore distances of 10's to 100's of kilometers. Thus, the medium - and large scale approach in nourishment policy is a pro-active approach to preserve safety against flooding.

The approach is well in accordance with the recommendations for coastal erosion management issued by the EU (Eurosion, 2004).

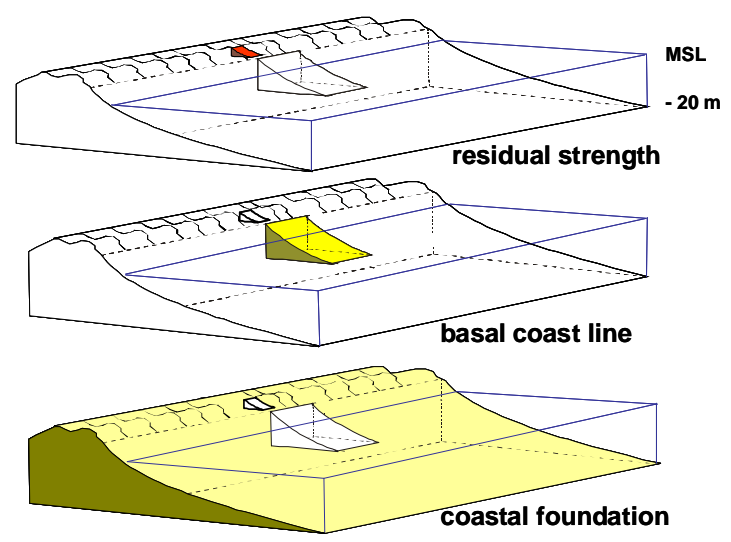

Fig. 2 Three different scales in coastal management (modified after Mulder et al., 2006)

\section{Pro-active nourishment approach is succesful}

The nourishment policy since 1990 has been succesful in maintaining the Basal Coast Line. As indicated by Fig. 3, the number of locations where the BCL is endangered, over the years remained constant.

In addition to that, Arens et al. (2010) in a study on the effects of nourishments on dune development, conclude an average increase of sedimentation in the dunes since 1990, resulting in a seaward extension of the dune foot. Although they cannot contribute this increase to nourishments 
with a $100 \%$ certainty - it still needs to be investigated whether the relative low number of storm surges since 1990 plays an important role -, it seems very likely the observed dune sedimentation is due to nourishments. Considering that wider dunes imply a larger buffer to dune erosion during storm surges, thus providing better protection against flooding, the conclusion of Arens et al. (2010) indicates that it is most likely the pro-active nourishment approach is succesful.

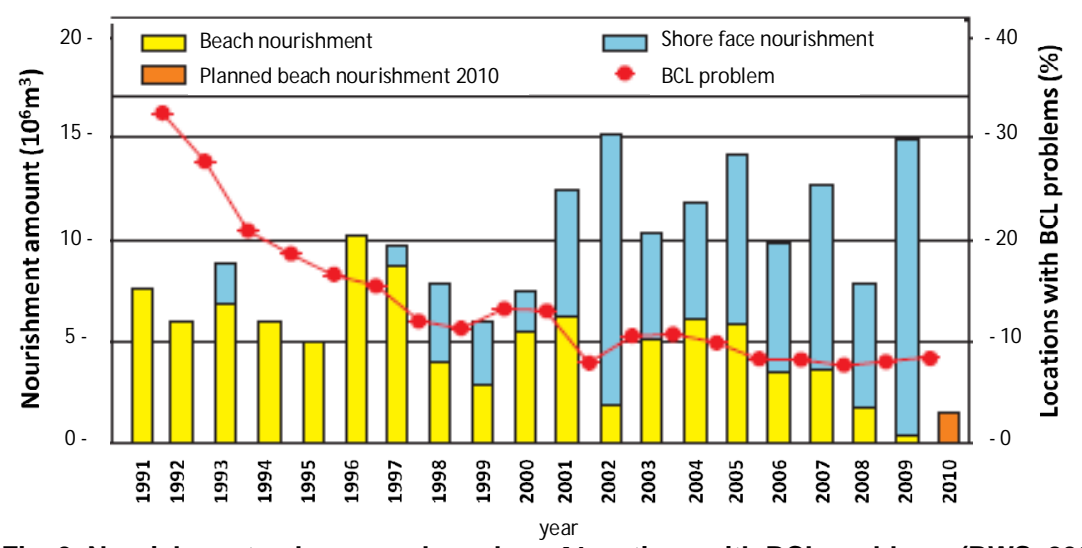

Fig. 3 Nourishment volumes and number of locations with BCL problems (RWS, 2009)

\section{UPSCALING OF NOURISHMENTS}

The present nourishment policy is based on a yearly averaged nourishment volume of $12 \mathrm{Mm}^{3}$. As shown above, nourishing this volume has succesfully contributed to achieve objectives at the small - and medium scale levels: preserving (and enhancing) dune strength and maintaining of the coast line. However, the contribution to the third and largest scale level (i.e. maintaining of the active sand volume of the coastal foundation) appears to be insufficient.

A latest update of the sediment balance of the coastal foundation (De Ronde, 2008) shows a negative total of ca. $20 \mathrm{Mm}^{3}$ per year. Considering that (-) Coastal Foundation, Wadden Sea and Western Scheldt represent one, active sand sharing system, (-) sediment transport over seaward and landward boundaries of the coastal foundation may be assumed to be negligible, and (-) the net balance of sediment transports over Belgian boundary in the South and German boundary in the North, may be assumed to be zero, De Ronde (2008) estimates three major sources determining the sand balance of the coastal foundation (see Fig. 4): first of all, the sand volume necessary to grow with sea level; next, the volume to compensate for the sediment accomodation space created by (historic) land reclamations, gas- and sand mining in tidal basins of Wadden Sea and Western Scheldt; finally, the volume to compensate for sand mining associated with the maintenance dredging of the entrance channels to the harbours of Rotterdam and Amsterdam.

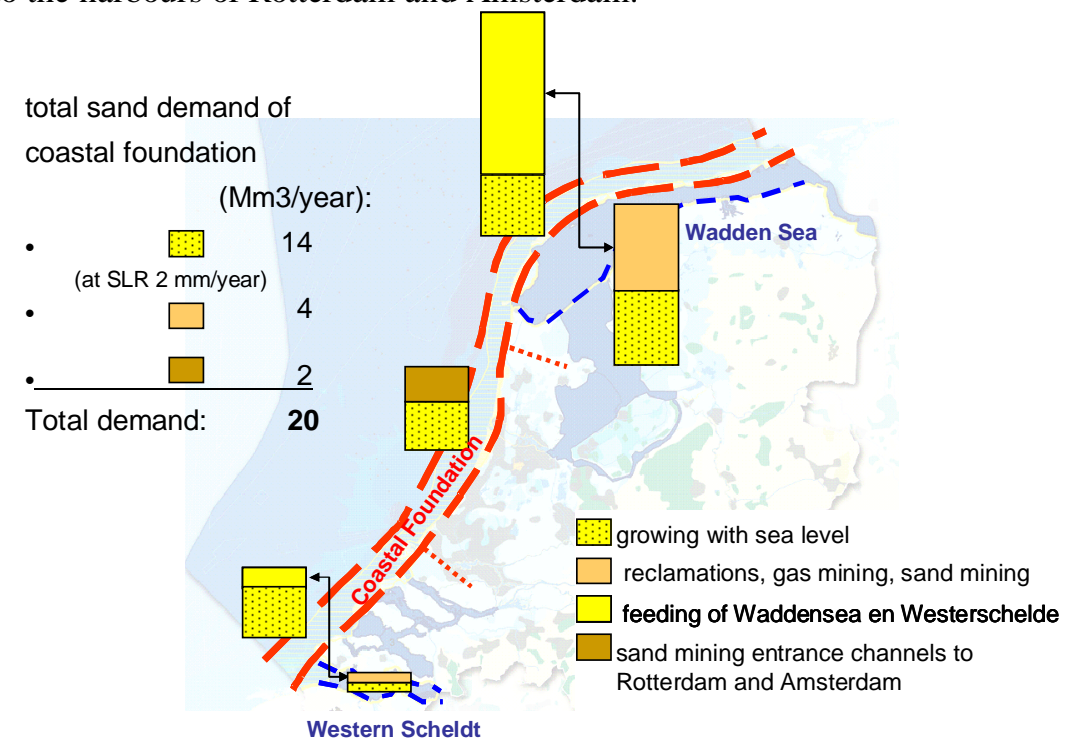

Fig. 4 Sand balance of the coastal foundation ( based on figures from De Ronde, 2008) 
The conclusion is that - in order to achieve the objective of maintaining the active sand volume of the coastal foundation - nourishments would need upscaling from 12 to $20 \mathrm{Mm}^{3}$ per year.

However, it is good to realize that this accounts for an estimated sea level rise of $2 \mathrm{~mm} /$ year. As an average observed value of sea level rise in the Netherlands over the last century (Dillingh et al., 2010), $2 \mathrm{~mm}$ /year in policy generally is regarded as a good approximation of actual sea level rise. To grow with such sea level rise rate, would require the mentioned upscaling to $20 \mathrm{Mm}^{3} /$ year; an higher rate of sea level rise, an equivalently higher upscaling.

In this respect, in a study on future adaptation options to climate change in the Netherlands, the authoritive Deltacommissie (2008) suggests a raise of nourishment budgets up to 85 million $\mathrm{m}^{3} / \mathrm{year}$ until the year 2050. Considering an ultimate worst case sea level rise scenario of $130 \mathrm{~cm}$ in 2100 , the Deltacommissie recommends a further pro-active respons by upscaling the yearly nourishment volume equivalent to a sea level rise of $13 \mathrm{~mm} / \mathrm{yr}$. The extra buffer this would create, might be beneficial to different societal functions.

\section{MEGA NOURISHMENT: PILOT SAND ENGINE}

In the light of discussions on upscaling nourishment volumes, the need was felt to investigate innovative ways of nourishing larger volumes of sand.

Initiated by the Province of South Holland, together with the Ministry of Transport, Public Works and Water Management, local municipalities and Water Board, NGO's and business, this has led to the definition of a Pilot Project "Zandmotor / Sand Engine". The pilot implies a mega-nourishment of approximately $20 \mathrm{Mm}^{3}\left(\sim 10,000 \mathrm{~m}^{3} / \mathrm{m}\right)$ on the coast of Holland, between Hook of Holland and The Hague (see Fig. 1). Objectives of the pilot are to create long term safety conditions in combination with extra space for nature and recreation, in an innovative manner.

After a planning period of two years and an Environmental Impact Assessment procedure, the implementation is planned for 2011, starting end 2010.

\section{DESIGN OF SAND ENGINE}

\section{Morphodynamic modelling}

In preparation of the pilot, several designs of a Sand Engine have been studied. In order to enable an evaluation of morphological effects of these designs on a time scale of 20 -50 years, a depthaverage morphodynamic Delft3D model (Lesser et al, 2004) of the South Holland coast has been set up using SWAN (Holthuisen, 1993) within the Wave module and TRANSPOR2004 (Van Rijn, 2007abc) as sediment transport model.

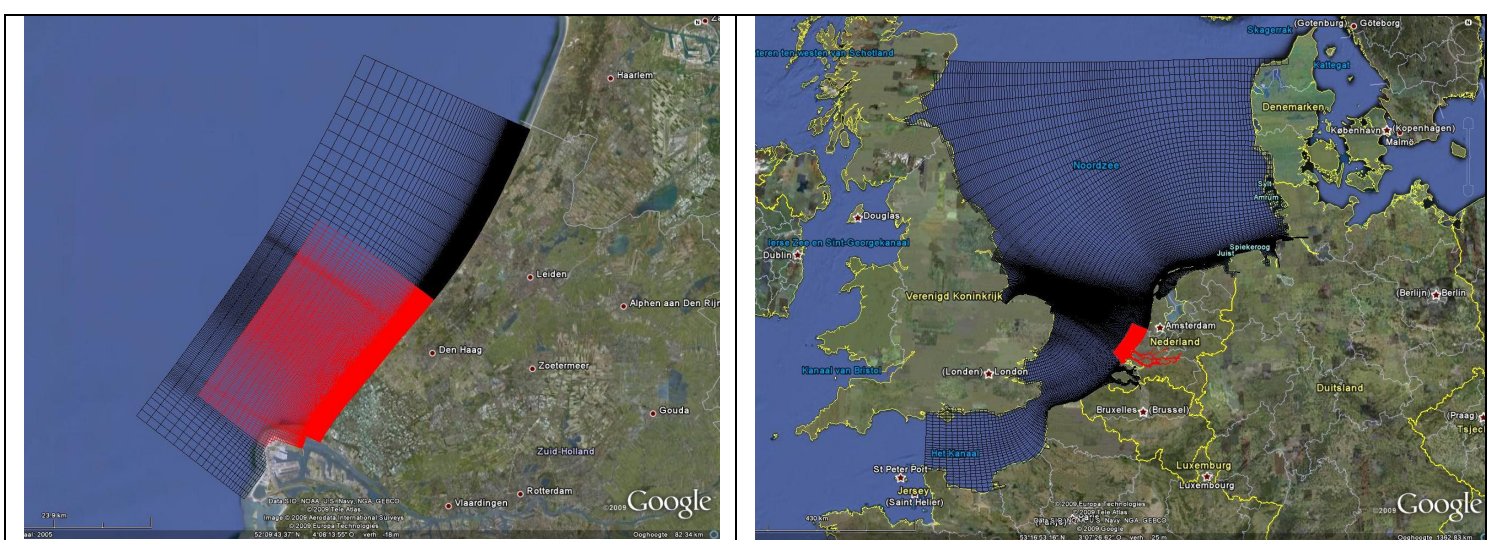

Fig. 5 Left: model domains for flow (red) and wave model (black). Right: ZUNO-FIJN domain (black) and ZEEDELTA v8 domain (red).

The flow domain comprises about $26 \mathrm{~km}$ alongshore and about $15 \mathrm{~km}$ cross-shore, while the wave domain stretches further to the south and north to minimize boundary effects (see Fig. 5a). The maximum grid resolution in both domains in the area of interest is $80 \mathrm{~m}$ alongshore by $20 \mathrm{~m}$ crossshore. The flow model applies Neumann boundary conditions (Roelvink and Walstra, 2004) at both lateral boundaries, water levels at the north-western (sea) boundary and a discharge at the entrance of 
the Nieuwe Waterweg entrance channel to the Port of Rotterdam in the SW. Boundary conditions were derived from the validated large-scale ZUNO-FIJN North Sea model (Roelvink et al, 2001) and the ZEEDELTA v8 model (Zijlema, 2003) (Fig 5b). Offshore wave data from wave buoys "Euro Platform" and "Meetpost Noordwijk" was classified into 10 wave height bins between $0.25 \mathrm{~m}$ and $5.25 \mathrm{~m}$ and in 12 directional bins between $195^{\circ} \mathrm{N}$ and $15^{\circ} \mathrm{N}$.

Tidal and wave boundary data have been schematized to result in the long-term net total transport fields. A so-called representative, morphological tide was derived using the method of Latteux (1995). A harmonic analysis using 16 components was performed over this period to result in a cyclic tidal signal, uneven components were removed following Roelvink (1998). A representative morphological wave climate was derived using the so-called "Opti" method developed by Roelvink (Lesser, 2009); based on a statistical description of the performance of wave conditions with respect to the net and gross transport fields, the method iteratively selects and removes the morphologically least determining wave conditions from the total set of wave conditions. The frequency of occurrence (weighting factors) of the remaining wave conditions are automatically adjusted to compensate for the removed wave conditions. Following this approach, a morphological wave climate of 10 wave conditions was derived. The parallel-online approach developed by Roelvink (2006), has been used to simultaneously compute the weighted bed changes resulting from these ten representative wave conditions. The uncalibrated net transport rates thus computed by the model, were found to be in the order of the net transport rates reported by Van Rijn (1997).

\section{Dune module}

Due to the fact that both long term safety and nature development are main objectives of the pilot Sand Engine, estimates of dune development were required. As formulations for intertidal-, beachand aeolian processes are lacking in the morphological model suite, a dedicated dune module has been developed and implemented following De Vriend and Roelvink (1989). Based on historic data of the Dutch coast, they reported an equilibrium beach width of approximately $125 \mathrm{~m}$ and derived an empirical relation between beach width and dune foot migration (Fig. 6), showing that the migration rate of the dune foot is equivalent with the difference between the actual beach width and it's equilibrium width. The empirical relation was implemented in the dune module to simulate horizontal migration of the dune foot.

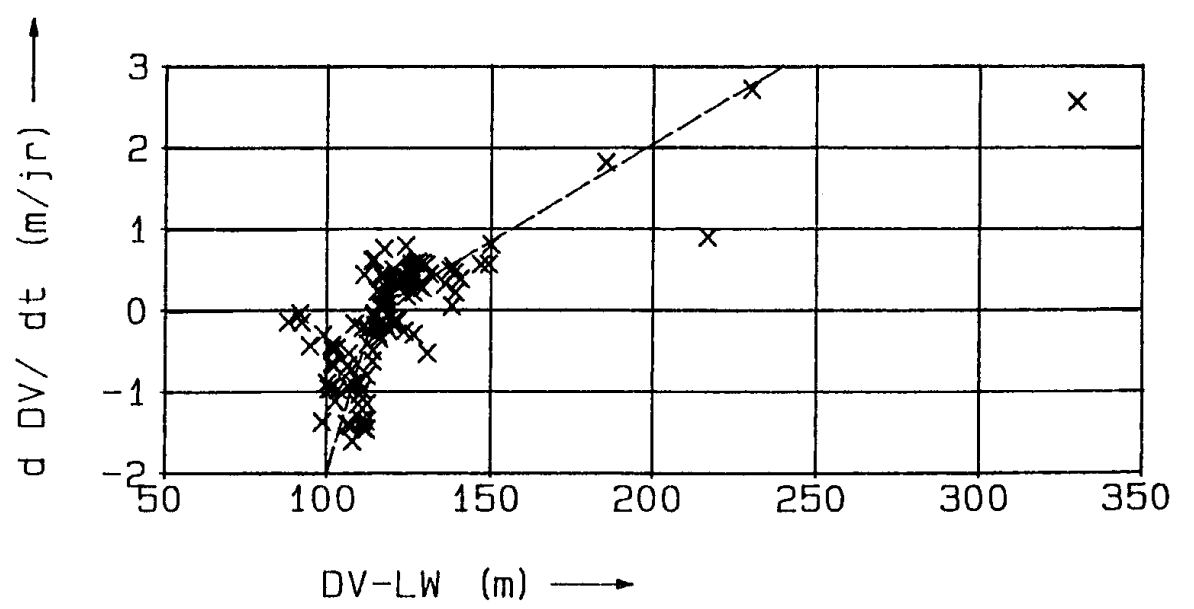

Fig.6 Dune foot migration [ dDV/dt ] as a function of beach width [ DV - LW ] (De Vriend and Roelvink, 1989), where $D V=$ dune foot and $L W=$ mean low water.

\section{Coastal maintenance}

To investigate the effect of a Sand Engine on the regular maintenance effort of the adjacent basal coast line and the coastal foundation, a schematized nourishment program was implemented in the model. The schematization implies the assumption of a nourishment frequency of 5 years, where erosive stretches along the coast are nourished using shore face nourishments at a depth of $-5 \mathrm{~m}$, with a volume equal to twice the calculated loss in the MCL-zone (i.e. Momentary Coast Line zone between +3 and -4.4 m; cf. Fig. 7; also see e.g. Van Koningsveld and Mulder, 2004). Sea level rise 
was assumed to be constant and equal to the present rate of $2 \mathrm{~mm} / \mathrm{year}$. As a consequence, the total nourishment volume to maintain the coastal foundation of the coastal cell of Delfland ( between Hook of Holland and The Hague), in the reference case without a Sand Engine, is $1.1 \mathrm{Mm} 3$ per year. The implemented nourishment program was found to maintain the (erosive) coastline at its position in the reference simulation with realistic nourishment volumes.

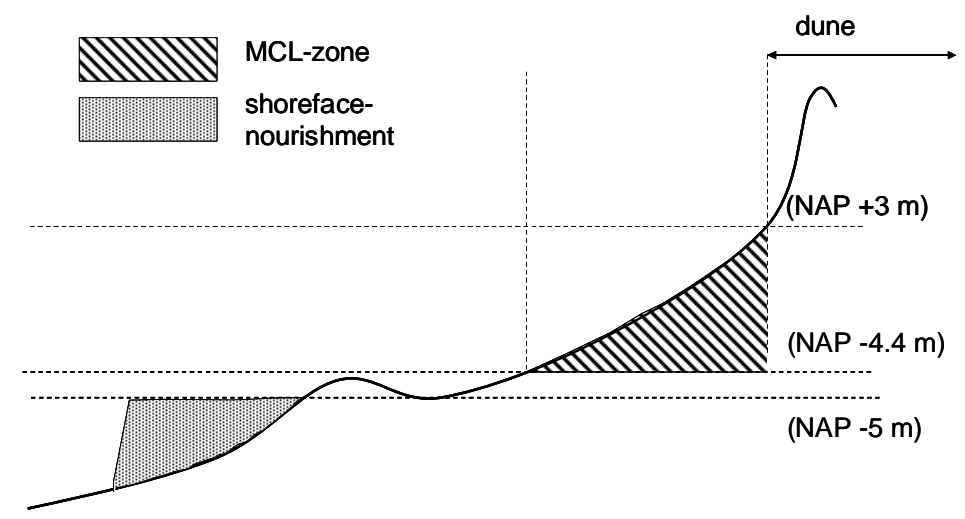

Fig. 7 Schematic representation of MCL-zone and shoreface nourishment with a volume of twice the loss of sediment in the MCL-zone

\section{Designs}

Numerous different locations and designs ranging from shore face nourishments, detached islands, peninslua's, shore-attached bars, bell and hook-shaped designs were modeled over periods ranging from 20 to 50 years. Based on costs, safety, ecological and recreational aspects the hookshaped design was selected as the so-called preferred alternative for the EIA. Fig. 8 shows Sand Engine designs for a shore face nourishment, a bell-shaped and a hook-shaped nourishment of 20 $\mathrm{Mm}^{3}$.

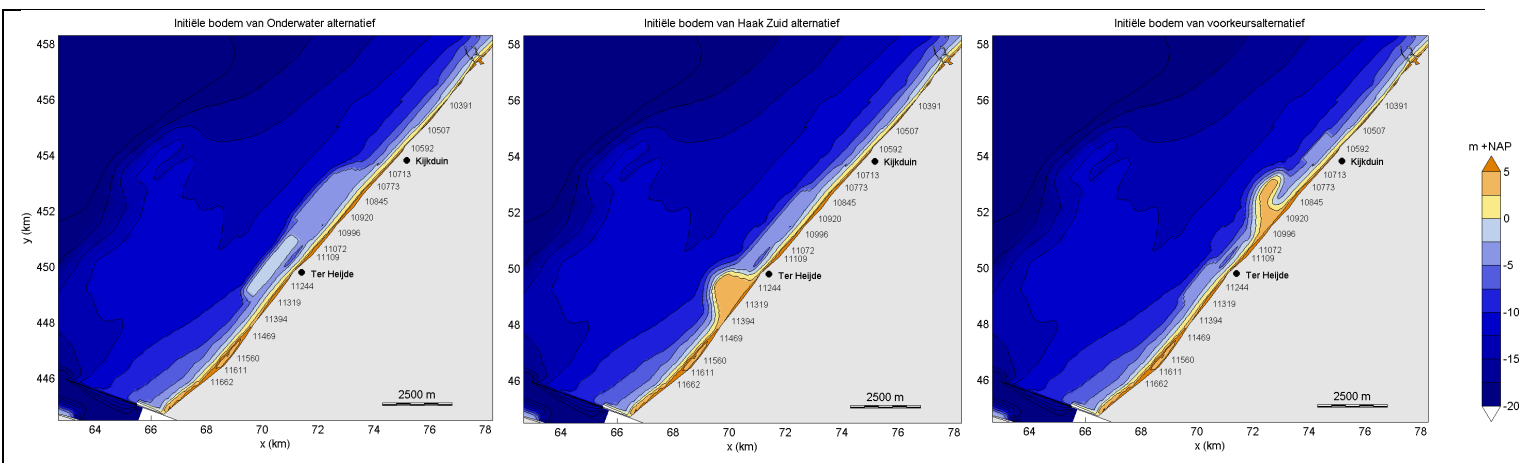

Fig. 8 Sand Engine designs as a shoreface nourishment (left), a bell-shaped (middle) and a hook-shaped nourishment (right) of $20 \mathrm{Mm} 3$

\section{Morphological development}

The different designs for the Sand Engine were evaluated based on computed wave fields, flow velocity fields, sediment transport fields, morphological evolution, sedimentation/erosion patterns, erosion of adjacent coastlines, necessary nourishment volumes and evolution of dune area. Results were compared to the reference simulation without a Sand Engine. For aggregated parameters such as the erosion volume of the MCL zone in time, a uncertainty of about $30 \%$ in magnitude and time was estimated based on sensitivity computations in which forcing conditions, model parameters and numerical settings were varied.

Figure 9 shows the computed morphological development of the hook-shaped alternative after 5, 10 and 15 years. It can be seen that in the morphodynamic simulation, the top of the hook is elongated in northern direction and pushed onshore, creating a shallow, sheltered area that is filled and emptied 
through a small channel. In time the elongated sand body is breached and a shallow plain is formed, ultimately leading to wide beaches. Sand is spread in both northern and southern directions. Overwash processes, which are not included in the model, may lead to faster breaching of the elongated sand body and thereby reducing the time that the sheltered area exists. Siltation rates in the sheltered area up to $0.1 \mathrm{~m}$ per year were estimated using a $1 \mathrm{DV}$ (point) model for erosion and deposition of silt.

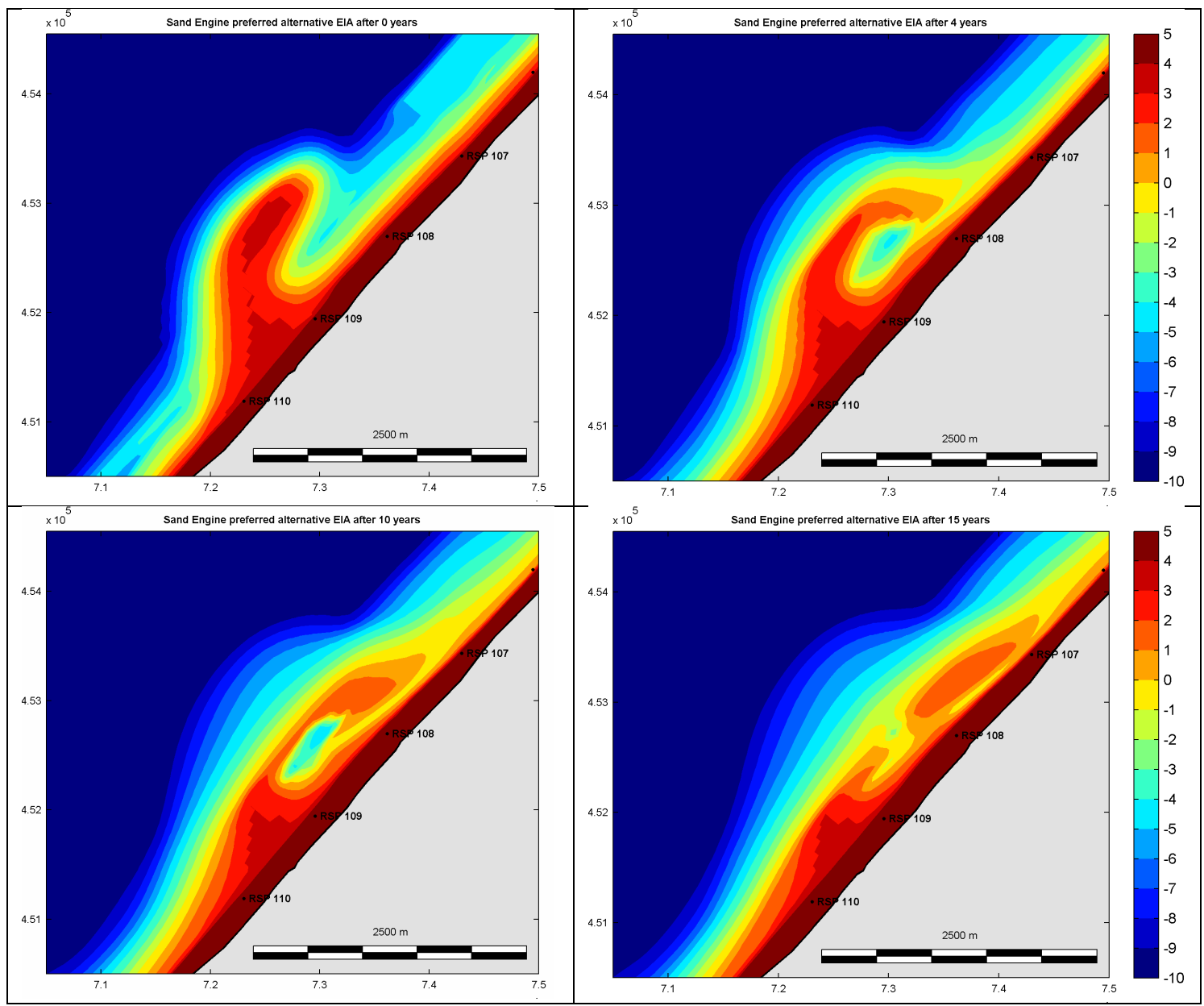

Fig. 9 Computed morphological development of hook-shaped design with the initial bathymetry in the upper left panel, the bathymetries after 5, 10 and 15 years in the upper right, lower left and lower right panel respectively.

\section{Dune development}

Based on the dune module, for each design the horizontal migration of the dune foot through time has been estimated, resulting in estimates of the change in total dune area for the Delfland coast. The results for three different designs (cf. Fig. 8) compared to a reference situation, are shown in Table- 1. All alternatives implied 5 yearly nourishments; in case of the different Sand Engine designs aimed at maintaining the coast line, in case of the reference situation aimed maintaining both coast line and coastal foundation. The nourishments were schematised according to the approach mentioned above.

\begin{tabular}{|l|l|l|l|l|l|}
\hline Table 1. Esimates of increase in dune area (ha) \\
\hline $\begin{array}{l}\text { Alternative } \\
\text { (c.f. Fig. 8) }\end{array}$ & after 1 year & after 5 years & after 10 years & after 15 years & after 20 years \\
\hline Reference & 0.2 & 2.6 & 6.2 & 10.8 & 17.0 \\
\hline Hook & 1.6 & 6.8 & 13.7 & 22.7 & 32.9 \\
\hline Bell & 1.2 & 7.0 & 16.6 & 28.0 & 38.8 \\
\hline Shoreface & 0.3 & 3.5 & 11.0 & 20.1 & 30.6 \\
\hline
\end{tabular}


The Sand Engine designs appear to create approximately twice as much new dune area as the reference situation without a Sand Engine. The dune creation by the three designs hardly shows significant differences. It is remarkable that the design of a megascale shore face nourishment, in the long term of twenty years or more, contributes to a dune growth comparable with the designs of a hook or bell.

As the dune growth contributes to a stronger dune, the model results indicate that a Sand Engine represents an effective method to enhance long term safety against flooding.

\section{Development in coast line maintenance}

The schematized nourishment program in the model produces indications of the effect of a Sand Engine on the nourishment effort to maintain the coast line adjacent to the Sand Engine. The results presented in Table 2 illustrate that on a 5 year basis, the nourishment volumes range from $1.2-2.0$ million $\mathrm{m}^{3}$ after 5 years to $0.7-0.9$ million $\mathrm{m}^{3}$ after 20 years.

\begin{tabular}{|c|c|c|c|c|c|c|}
\hline $\begin{array}{l}\text { Alternative } \\
\text { (c.f. Fig. 8) }\end{array}$ & after 5 year & after 10 years & after 15 years & after 20 years & $\begin{array}{l}\text { total } \\
\text { maintenance }\end{array}$ & $\begin{array}{ll}\text { Sand } & \text { Engine } \\
\text { volume }\end{array}$ \\
\hline Reference & 5.5 & 5.9 & 5.3 & 6 & 22.6 & - \\
\hline Hook & 2.0 & 1.5 & 1.2 & 0.9 & 5.6 & 20 \\
\hline Bell & 1.3 & 0.6 & 0.7 & 0.7 & 3.3 & 20 \\
\hline Shoreface & 1.4 & 1.1 & 0.8 & 0.9 & 4.2 & 20 \\
\hline
\end{tabular}

Interesting is the comparison of the Sand Engine alternatives with the reference case (Table 2). In the latter, the schematized nourishment scheme implies a 5 yearly nourishment to an amount equal to the volume enabling the coastal foundation to grow with the sea level. As indicated earlier, this is 5.5 million $\mathrm{m}^{3}$ per 5 years at a sea level rise of $2 \mathrm{~mm} /$ year. Then, considering the total sand input to the system after 20 years, it appears the total input by each of the Sand Engine alternatives is larger than in the reference case: 23.3 - 25.6 million $\mathrm{m}^{3}$ compared to 22.6. The break even point of Sand Engine alternatives and the reference approach probably is reached somewhere after 22 years. In other words, the Sand Engine alternatives and additional coast line nourishments are sufficient to maintain the coastal foundation for a period of approximately $22-25$ years. After that period, in case of the sand Engine designs of 20 million $\mathrm{m}^{3}$, additional nourishments will be required to maintain the coastal foundation. If the rate of sea level rise might increase, this moment will be earlier.

\section{DISCUSSION AND CONCLUSION}

New insights into the sediment balance of the Netherlands coastal system and recommendations on climate change adaptation, recently have triggered a discussion on upscaling of coastal nourishments. Combined with the need to investigate innovative ways of coastal maintenance and coastal development, this has resulted in the definition of a Pilot Sand Engine Delfland; a mega scale nourishment of 20 million $\mathrm{m}^{3}$ to be implemented at the Holland coast between Hook of Holland and The Hague in 2011.

In the design phase of the Sand Engine, morphodynamic model calculations of various alternatives have contributed to decision making by estimating morphological effects and changes in important indicators, especially coast line maintenance and dune development. The latter representing an important indicator of the (long term) change in safety against flooding and of (terrestrial) nature development; two of the main objectives of the Pilot Sand Engine. To enable estimates of dune development, the morphodynamic model Delft3D was extended with a dune module, based on an empirical relationship between beach width and dune foot migration.

Calculations have shown that the long term (20 - 50 years) morphological effects of different alternatives are quite similar. Considering the objectives of the pilot to create long term safety conditions in combination with extra space for nature and recreation, in an innovative manner, the Environmental Impact Assessment (EIA, 2010) has decided on the Hook (cf. fig. 9) as the preferent alternative. Especially from a point of view of nature development it is expected the Hook may create interesting intertidal habitats. In addition to that, estimates of dune development for the Hook indicate 
a doubling of the increase rate of the dune area, compared to the reference situation.; an increase of dune habitat and contribution to a stronger dune, enhancing safety against flooding.

Regarding the effect of a Sand Engine on maintenance of the coast line, model estimates indicate that additional nourishments will be necessary adjacent to the Sand Engine. Through time the efforts decrease gradually parallel to the redistribution of the Sand Engine along the coast.

Taking into account that at the present rate of sea level rise, the coastal foundation of Delfland requires approximately 5.5 million $\mathrm{m}^{3}$ per 5 years in order to grow with the sea level, it is not surprising that a Sand Engine of 20 million $\mathrm{m}^{3}$ is contributing to the maintenance of the coastal foundation for a period of around 20 years. Model estimates indicate this period to be around 25 years in case of a Hook shaped Sand Engine and additional 5 yearly nourishments to maintain the coast line ( Table 2).

\section{ACKNOWLEDGEMENTS}

Different sources from which the work is funded are: Provincie Zuid-Holland under contract 1201001, Water Innovation Program (WINN) of Rijkswaterstaat, Building with Nature program of Ecoshape under project HK4.1 and the EU FP6 project CONSCIENCE ( proj. contract nr. 044122 ).

\section{REFERENCES}

Arens, S.M., S.P. van Puijevelde en C. Briere. 2010. Effecten van suppleties op duinontwikkeling. Geomorfologie. Rapportage fase 2. ARENS BSDO. RAPPORTNR. RAP2010.03. Amsterdam. 125 pp. ( in dutch)

Deltacommissie. 2008. Working together with water; a living land builds for it's future. Findings of the Deltacommissie 2008 (www.deltacommissie.com)

De Ronde, J.G. 2008. Toekomstige langjarige suppletiebehoefte.Deltares report Z4582.24, Delft,

De Vriend, H.J. and D. Roelvink. 1989. Innovatie van kustverdediging :inspelen op op het kustsysteem. Kustverdedigin na1990, techn rapport 19. WL | Delft Hydraulics (in dutch)

Dillingh, D., F. Baart and J.G. de Ronde.2010. Definitie van zeespiegelstijging voor bepaling suppletiebehoefte. Rekenmodel t.b.v. handhaven kustfundament. Deltares report 1201993.002, Delft, juli 201066 pp. ( in dutch)

EIA, 2010. Projectnota MER Aanleg en zandwinning Zandmotor Delflandse kust. Provincie Zuid Holland i.s.m. Ministerie van Verkeer en Waterstaat, Gemeente Den Haag, Gemeente Westland, Hoogheemraadschap van Delfland, Milieufederatie Zuid-Holland (www.kustvisie.nl/zandmotor)

Eurosion, 2004. Living with coastal erosion in Europe; sediment and space for sustainability. Euopean Commission.Luxembourg: Office for Official Publications of the European Communities, 2004. p. 40 (www.eurosion.com).

Holthuijsen, L.H., Booij, N., and Ris, R.C. (1993). A spectral wave model for the coastal zone. Proc. of the $2^{\text {nd }}$ Int. Symposium on Ocean Wave Measurement and Analysis, New Orleans, 630-641.

Lesser, G.R. (2009). An approach to medium-term coastal morphological modeling. PhD thesis UNESCO-IHE Institute for Water Education, Delft.

Latteux, B. (1995). Techniques for long-term morphological simulation under tidal action. Marine Geology 126 129-141.

Lesser, G., Roelvink, J.A., Van Kester, J.A.T.M. and Stelling, G.S. (2004). Development and validation of a three-dimensional morphological model. Journal of Coastal Engineering Vol. 51, pp 883-915.

Mulder, Jan P.M., Gertjan Nederbragt, Henk J. Steetzel, Mark van Koningsveld, Zheng B. Wang. 2007. Different implementation scenarios for the large scale coastal policy of the Netherlands, Proc. 30 ${ }^{\text {th }}$ Int.Conf.Coast.Eng, San Diego USA, Vol. 2 (1705 - 1717)

Rijkswaterstaat (RWS).2009. Kustlijnkaarten 2010. Rijkswaterstaat Ministerie van Verkeer en Waterstaat. Den Haag december 2009. 165 pp. (www.kustlijnkaarten.nl)

Roelvink, D. 2006. Coastal morphodynamic evolution techniques. Journal of Coastal Engineering 53 (2006); 277-287

Roelvink, J.A. and Walstra D.J.R., 2004. Keeping it simple by using complex models, 6th Int. Conf. on Hydroscience and Engineering (ICHE-2004), May 30-June 3, Brisbane, Australia

Roelvink J.A., Van Holland, G. and Bosboom, J., 1998. Morphological study MV2, Phase 1. Validation morphological modelling Haringvliet entrance (in Dutch), WL | Delft Hydraulics, report Z2428, Delft, The Netherlands 
Roelvink, J.A., Van der Kaaij, T., Ruessink, B.G., 2001. Calibration and verification of large-scale 2D/3D flow models. Phase 1, Parcel 2, Subproduct 2, ONL FLYLAND report. WL | Delft Hydraulics report Z3029.11, Delft, The Netherlands.

Van Koningsveld, M. and J.P.M. Mulder, 2004. Sustainable Coastal Policy Developments in the Netherlands. A Systematic Approach Revealed. Journal of Coastal Research, 20(2), 375-385. ISBN0749-0208

Van Rijn, L.C. (1997). Sediment transport and budget of the central coastal zone of Holland. Coastal Engineering No. 32 p 61-90.

Van Rijn, L.C.( 2007a). United view of sediment transport by currents and waves I: Initiation of motion, Bed roughness and Bed load transport. Journal of Hydraulic Engineering, ASCE, Vol. 133, No. 6, p.649-667.

Van Rijn, L.C.( 2007b). United view of sediment transport by currents and waves II: Suspended transport Journal of Hydraulic Engineering, ASCE, Vol. 133, No. 6, p. 668-689.

Van Rijn, L.C.( 2007c). United view of sediment transport by currents and waves III: Graded Beds. Journal of Hydraulic Engineering, ASCE, Vol. 133, No. 7, p. 761-775.

Zijlema, M. (2003). Reproductie nauwkeurigheid van het 3D Zeedelta-model v8. Ministerie van Verkeer en Waterstaat, Rijkswaterstaat, Rijksinstituut voor Kust en Zee ( RWS, RIKZ). 